\title{
Zionist Pioneers at the Shores of the Scheldt, the Hashomer Hatzair Youth Movement in Antwerp, 1924-1946
}

Janiv Stamberger

\section{(2) OpenEdition Journals}

Electronic version

URL: http://journals.openedition.org/cmc/367

DOI: $10.4000 / \mathrm{cmc} .367$

ISSN: 2684-3080

\section{Publisher}

Fondation de la Mémoire Contemporaine

\section{Printed version}

Date of publication: 1 December 2014

Number of pages: 67-104

ISSN: 1377-1256

\section{Electronic reference}

Janiv Stamberger, «Zionist Pioneers at the Shores of the Scheldt, the Hashomer Hatzair Youth Movement in Antwerp, 1924-1946», Les Cahiers de la Mémoire Contemporaine [Online], 11 | 2014, Online since 05 November 2019, connection on 10 December 2020. URL : http://journals.openedition.org/ cmc/367 ; DOI : https://doi.org/10.4000/cmc.367 


\title{
Zionist Pioneers at the Shores of the Scheldt The Hashomer Hatzair Youth Movement in Antwerp, 1924-1946
}

\author{
Janiv Stamberger
}

With the arrival of a new wave of Jewish immigrants in the 1920's, Belgium's pre-existing Jewish community became radically transformed. These new immigrants, the vast majority of whom were from Eastern Europe, brought with them a specific Jewish culture and certain new ideologies that had not existed (or had scarcely existed) in Antwerp. Liberal zionism already had a strong tradition in Belgium, with its first circles having been established in the $19^{\text {th }}$ century ; however, it was only with the arrival of these (mostly poor) immigrants that a strong labour zionist party began to develop in the country ${ }^{1}$. In addition to the liberal and labour zionist movements, a strong religious zionist movement was also established in the first quarter of the $20^{\text {th }}$ century $^{2}$. Each of these organisations maintained its own youth movement. Outside the zionist movement, a strong communist ideology was discernible in the Jewish community. In Brussels, the Jewish branch of the communist movement was able to infiltrate the Jewish trade union movements and enjoyed a relatively strong position amongst Jewish labourers in the small-scale luxury handicraft occupations $^{3}$. Whilst the Orthodox and Ultra-Orthodox Jews did not yet have the prominent position they would attain after the Second World War, they nonetheless formed a sizable minority in Antwerp's Jewish community. In short : after the First World War, a markedly heterogeneous community of myriad political ideologies, parties and organi-

\footnotetext{
${ }^{1}$ Both the Linke Poale Zion as the Poale Zion in Belgium were established in 1921. Read : R. Van Doorslaer, Kinderen van het Getto, Joodse revolutionairen in België (1925-1940), Antwerp, 1995, pp. 30-31 ; Id., Het Belgische Jiddischland. Een politieke geschiedenis van de joodse gemeenschappen in België tussen de twee wereldoorlogen in onderhavige Bijdragen.

${ }^{2}$ E. Schmidt, Geschiedenis van de joden in Antwerpen in woord en beeld, Antwerp-Rotterdam, 1994, p. 129 ; R. Van Doorslaer, op. cit., p. 29.

${ }^{3}$ About the history of the Jewish communists in Belgium in the interwar period,read : R. Van Doorslaer, op. cit.
} 
sations came to establish itself on the shores of the Scheldt. Often these parties and organisations retained strong links with the founding bodies in their countries of origin, and thus served their local constituencies with varying degrees of independence. This article will focus on one of these newly established organisations, the Hashomer Hatzair of Antwerp ${ }^{4}$.

The Hashomer Hatzair youth movement was established in 1913, in Galicia, through the merger of the Hashomer organisation - a Polish Jewish scouting and athletic movement which touted physical activity as a way to harden and discipline disenfranchised Jewish youth - and the Tseirei Tsion.

The Tseirei Tsion consisted of student and secondary school societies whose members sought to improve their knowledge of Jewish matters. These societies continued the traditions of the Haskalah (Jewish enlightment) and of the casuistic system of reasoning in the Talmudic tradition, and were imbued by a strong Jewish national spirit ${ }^{5}$. Hashomer Hatzair would inherit both the scouting tradition and the strong emphasis on self-development which had formed the respective cores of its two predecessor movements.

It is hardly surprising that Hashomer Hatzair's primary objective was the revitalization of Jewish youth. The reason for this must be sought in the specific conditions that had pervaded Galician Jewish society (and indeed East European Jewish society) from the end of the $19^{\text {th }}$ century through the first quarter of the $20^{\text {th }}$ century. With the advance of capitalism, the traditional structures of Jewish society in Eastern Europe began to disintegrate. This eroded the economic foundation of Jewish society, which since the Middle Ages had been based largely on trade in various handicraft goods. Many people fell into poverty and the standard of living (which had been relatively low to begin with) declined markedly. These economic hardships were exacerbated by substantial growth in the Jewish population and by regular outbreaks of often violent antisemitism. This led to massive Jewish

\footnotetext{
${ }^{4}$ E. Margalit, « Social andIntellectual Origins of the Hashomer Hatzair Youth Movement, 1913-20 », inJournal of Contemporary History, vol.4, 2, 1969, p. 29.

${ }^{5}$ The Haskalah movement (Jewish enlightenment) started at the end of the $18^{\text {th }}$ century inspired by figures like the German Moses Mendelsohn and sought to reform Judaism and bring it closer to the customs and traditions of non Jewish European culture.
} 
migration to the United States (the destination of most Jewish emigrants), South American countries and Western Europe. While the majority of Jews in Eastern Europe still adhered to traditional orthodox faith or belonged to any of the various Chassidic groups in Eastern Europe, a minority of them, mostly from the more educated and wellto-do population of Jewish society, embraced the ideas of the Haskalah movement. It was from within these groups, and especially from amongst the younger generation, that the foundations were established for the organisations that would become Hashomer Hatzair.

These youths desperately sought to break away from traditional Jewish society and endeavoured to become part of the general (predominantly non-Jewish) Polish society. They thereby engaged in a protracted journey of assimilation which included adopting and identifying with Polish national culture and aspirations. Yet, for all their efforts, Polish society seemed reluctant to accept them and rejected their claims of citizenship. This left the youth in a state of perplexed anxiety, for not only had they been denied any place in Polish society but they also could not connect to the traditional (yet now deficient) social structures of Jewish life and community. As a result, they turned to a form of Jewish cultural nationalism. In this respect, they emphasised the struggle against assimilation and engaged in educational, cultural and athletic activities. They formed a kind of alternative identity, in which they rejected both traditional Judaism and the premise of assimilation which was inherent in the Haskalah movement. Instead, they set out to create a new, revived Jewish identity that would meet the challenges of the times ${ }^{6}$.

It was from this set of specific historical circumstances that the Hashomer Hatzair movement came into being. In shaping their identityits members were inspired by a range of intellectual traditions. They absorbed ideas from Sigmund Freud, Martin Buber, Otto Weininger and Arthur Schopenhauer. From Gustav Wyneken they took the idea of a Society of Youth with its own values and ethos that would set it apart from adult society. The basic preoccupation of the movement was to revitalize the Jewish youth such that that it would again be whole and healthy. In short, the movement strove for its members -

${ }_{6}^{6}$ E. Margalit, op. cit., p. 28. 
men and woman, boys and girls - to strong in both mind and body, so as to resemble the ancient Hebrews as described in the biblical book of Prophets as opposed to the decayed, overly intellectual Jew of the Diaspora ${ }^{7}$.

Although the Hashomer had shown socialist tendencies from the beginning, it was only in the years 1926-1927, in Palestine, that they adopted left-wing revolutionary marxism, which would characterise the movement in its later years. The principles of class struggle and historical materialism were accepted on the condition that these principles should be postponed until establishment of the Jewish State and introduction of a sizable Jewish proletarian mass. While the Hashomer Hatzair was part of the left-wing organisations in Palestine, it was not aligned with any political party, either in the yishuv or abroad. It relied instead on its own kibbutz federation (Kibbutz artzi) for a political platform.

After its establishment, in 1913, the movement continued to grow and expand consequent to Jewish emigration. In 1939, before the outbreak of the Second World War, the international movement counted around 70000 members, with chapters in North and South America, North Africa and throughout Europe, including Belgium ${ }^{8}$.

\section{The transformative period}

In Belgium, as in countries such as Tunisia and France, Hashomer Hatzair did not begin as a separate organisation but instead evolved from an already pre-existing Jewish zionist scouting movement. In 1920 a Jewish scouting organisation with clear zionist tendencies was established in Antwerp, under the name Jewish National scouting organisation Bar Kokhba. This movement was established by two brothers, Maurice (Monjek) and Jacob (Jakush) Kincler. Both had been born in Kutno, in Congress Poland, and had moved to Antwerp prior to World War I9.

\footnotetext{
7E. Margalit, op. cit., pp. 32-33.

${ }^{8}$ « Ha-Shomer Ha-Za'ir », in M. Berenbaum - F. Skolnik (eds.), Encyclopaedia Judaica, 2nd ed., vol. 8, 2007, pp. 382-385.

${ }^{9}$ In 1915, a Jewish scouting organisation wasalready established in Scheveningen (Netherlands) where a large colony of Jewish refugees had settled after fleeing Belgium at the outbreak of the
} 
Bar Kokhba, which was heavily influenced by the ideas of Baden Powel and the scouting tradition, organised myriad activities for Jewish youth. The emphasis was on scouting, with Sunday trips to the countryside and training in orientation, sports and games, etc. ; however, Jewish cultural and national education also formed an integral part of the movement's activities. The use and promotion of Hebrew was encouraged. The age groups and leadership positions had Hebrew names, and Hebrew language courses were given to older members. Younger members learned Hebrew songs and basic sentences. The idea of aliyah (immigration to Erets Israel) played a key part in the movement's ideology, although at the time actual immigration was not yet a viable option. There were no established hakhsharah centres where potential emigrants could prepare for their new life in Palestine, nor were any organisations promoting aliyah. Thus, in the early 1920's, most zionist movements in Belgium, including Bar Kokhba, engaged in cultural work, helped to raise financial funds (such as by participating in financial activities to benefit the KKL(the Keren Kayemeth Le Israel, the Jewish National Fund) and raised awareness about the plight of the yishuv and the zionist cause in their local communities.

The movement, though apolitical, was well integrated into zionist life. It maintained strong ties with other zionist organisations and Jewish institutions and regularly attended their events and festivities. Bar Kokhba was certainly not a religiously orthodox or ultra-orthodox youth movement, yet religious observance and education were a key element of the movement's identity. At the annual summer camps morning prayers were held and there was strict separation between boys and girls, including the respective campsites being several hundred meters apart. During the day, however, the campers partook in mixed activities ${ }^{10}$.

Initially (1920-1921), most of Bar Kokhba's members were children of second-generation immigrants who had been born and raised in Antwerp. The members came from all walks of life, and included chil-

First World War. Later members of this organisationwould become part of Bar Kokhba in Antwerp. Read :S. Brachfeld, Uit vervlogen tijden, wetenswaardigheden uit het Antwerps Joods Historisch Archief, Antwerp, 1987, pp. 93-111.

${ }^{10}$ S. Brachfeld, op. cit, p. 111 ; Antwerps Joods Historisch Archief - Sylvain Brachfeld (AJHASB), Audio-735, J. Scouts, Olei Belg, Maccabi, Joodse Padvinders (18.01.1987 - 31.12.1987). 
dren of privileged and working-class families alike. With the onset of large-scale immigration from Eastern Europe, increasing numbers of youths from among the recently arrived immigrants joined Bar Kokhba. During this period, the question first arose within the movement as to alignment with the Hashomer Hatzair in Poland.

These new members of Bar Kokhba had often been active in local zionist youth movements in their countries of origin, and many had been in Hashomer Hatzair (one of the first zionist youth movements). They came to Bar Kokhba telling stories about the activities of Hashomer Hatzair in Poland, and there gradually emerged in Bar Kokhba an interest in becoming part of the movement. In 1924 Emile ("Tarzan") Akkerman, a delegate from Bar Kokhba, was dispatched to Poland to establish contact with the Hashomer Hatzair and to gather information. Akkerman returned to Antwerp full of enthusiasm and proposed that Bar Kokhba should align itself with Hashomer Hatzair. After several weeks of animated discussion, a motion was passed to that effect.

Most of the Bar Kokhba members accepted the decision, despite knowing little about the Hashomer Hatzair other than that it was a socialist (not yet revolutionary marxist, as would happen two to three years later, in 1926-1927) and zionist movement and that it was developing into an important youth movement throughout Europe. A minority within Bar Kokhba, centred around the figure of Adolf (Dolf) Neulinger, refused to become involved in a politically orientated movement and left the organization ${ }^{11}$.

By the end of 1924 a ken (nest) of Hashomer Hatzair was formed in Antwerp, one of the first in Western Europe. A second ken was established in Belgium in 1926, in Brussels, and in the end of the 1930's a third, in Liège ${ }^{12}$.

\footnotetext{
${ }^{11}$ AJHA-SB, Audio-704, Familie Gunzig, Scouts Bar Kokhba, Israel.

${ }^{12}$ In the archives, Yad Yaari Hashomer Hatzair Institute for Research and Documentation, we found a mention of an apparently failed attempt to establish a ken in Charleroi in 1934 (Yad Yaari, (3)2.11-2, Folder 2, Letter, March 1934).
} 


\section{Structure of the movement}

With the decision of Bar Kokhba to align itself with the Hashomer Hatzair movement, the latter became part of a growing worldwide movement with a specific structure. The central organisation, from which directions and instructions were given to the local Hashomer Hatzair branches around the world, was called the hanhagah elyonah (world leadership), and was located in Warsaw. It was responsible for guiding the local branches in their organisation and in educational matters. From Warsaw, as well as from Palestine, envoys called shlikhim (singular :shaliakh) were sent to the various local (national) branches. The shlikhim were part of the leadership council and aided local organisations in their work. In this way the world leadership gained insight into the activities of the organisations and could intervene if a local branch deviated too far from the positions of the movement. In Belgium the first shaliakh arrived in the 1930's's. A second important centre of Hashomer Hatzair was in Palestine, where the movement's kibbutz was located and where Meir Yaari, the historic leader of the organisation, lived. From Palestine instructions and shlikhim were sent to Europe.

In each country where one or more kinim of Hashomer Hatzair were located the hanhagah rashit (head leadership) formed the highest organisational body. It represented all the kinim on a national level. It also maintained contact with the hanhagah elyonah, informing it about the proceedings of the various kinim in the country as well as corresponding with hanhagot rashiot in other countries. Each hanhagah rashit was composed of the shaliakh, a secretary (mazkir/a) and a few older madrikhim and the rosh ken of the various kinim. In Belgium, this was not a permanent body; the members came together a few times each month to discuss the progress of the movement. The office of Belgium's hanhagah rashit was in Antwerp.

In Belgium, two institutions were involved in matters of educational policy and guidelines for the work in the kinim. The moetzet me-

\footnotetext{
${ }^{13}$ D. Michman, «The Belgian Zionist Youth Movements during the Nazi Occupation », in D. Michman (ed.), Belgium and the Holocaust : Jews, Belgians, Germans, Jerusalem, 1998, pp. 383384 .
} 
nahalim klalit (general leader council) was organised on the national level (combining the kinim), while each ken had a local moetzet menahalim (leader council) tasked with the work of each individual ken in their city ${ }^{14}$.

As noted, there were three kinim in Belgium : in Antwerp, Brussels and Liège. The leadership consisted of several older madrikhim (leaders) and was presided over by the rosh ken (head of the ken); together they formed the hanhagah mekomit (local leadership).

The leadership of the ken and of the other institutions changed often, as older members of the movement were expected, and even obliged, to make aliyah and settle in one of the movement's kibbutzim in Palestine. Thus, at fairly regular intervals there was renewal and rejuvenation in the movement's leadership. Central figures in the Hashomer Hatzair in Antwerp during the interwar period included Numa Eisenzweig, in the first period, until around 1930 ; he was succeeded by Moshe Lerner ("Sheeta") and Benno Ausübel, who both served until around 1933 ; Mordechai Sercarz ("Pitah") then served, until just before the Second World War. Following the war, Nathan Dubinsky and David Donner appear to have been two of the principal leaders of the movement in Antwerp.

Each ken (nest) was organised into different groups according to age and size. The smallest group to which the khaver/a (friend), the name for a member, belonged was called a kvutsah. These were small groups of up to eight-ten members of the same age. In the period before the war, these groups were divided by gender. Each kvutsah was led by a madrikh/a (male or female leader), who was responsible for the education and well-being of the group members. The madrikhim, also referred to as menahalim, received special pedagogical training from the movement, so as to be suitably prepared for their leadership role ${ }^{15}$. Each kvutsah received a Hebrew name. For example, in 1942, we find a kvutsah named Arazim (Cedars) ${ }^{16}$.

Another group, combining several kvutsot, was called a plugah (company). A plugah consisted of all members (boys and girls alike) of

\footnotetext{
${ }^{14}$ Yad Yaari, (4)2.11-2.

${ }^{15}$ Yad Yaari, (5)2.11-2, 1935-1937, Folder 3, Journal of Hashomer Hatzair, 3, 1936, p. 14.

16Moreshet, D.1.6326-03,Kvutsah booklet.
} 
a certain age. For example, a kvutsah of 13-year-old girls and a kvutsah of 13-year-old boys together formed a plugah. Some of the movement's activities were organised within the smaller kvutsot; other activities, like games and scouting excursions, were organised within the larger plugot. Each plugah had a different Hebrew name.

Above the plugah was an even larger group, the gdud (battalion). However, in the sources the difference between these two groups is ambiguous and the terms plugah and gdud are often used interchangeably, though linguistically they clearly indicate different composition and form.

The number of gdudim depended on the size of the ken. When the ken was large more gdudim were established; when membership dropped, some gdudim were disbanded or merged. It is therefore difficult to give numbers or names (Hebrew) for all the gdudim at any given time; however, certain general terms can be applied which were used throughout the period and in all Hashomer Hatzair branches around the world ${ }^{17}$.

The kfirim (young lions), the youngest age group, were around 1012 years of age. They were followed by the tsofim (scouts), who were around 14 years old. Next were the tsofim bogrim, around 16-17 years old. The oldest age group was known as the bogrim (adults); the organisation's leadership and the madrikhim of the various kvutsot were chosen from its ranks. These older members were expected to prepare for aliyah and for life in a kibbutz in Erets Israel. A group of bogrim who were about to join or establish a kibbutz was called a garin (nucleus or seed).

This official structure formed an integral part in the workings of the movement, yet there also existed an equally important yet unofficial network. The personal ties which developed between members of different kinim and national branches also served as an important means for exchanging news and views. Members from different countries exchanged letters and formed strong friendships. After the outbreak of the war and with the collapse of most of the movement's offi-

\footnotetext{
${ }^{17}$ For a snapshot of the different gdudim in 1933 and 1938, see : J. Stamberger, Be Strong and Brave! A Small Youth Movement in a Sea of History. The Hashomer Hatzair Antwerp (19201948), unpublished Master thesis, UGent, 2013, p. 32.
} 
cial networks, these unofficial networks proved to be a lifeline for the movement.

\section{Members and social background}

Although I did not find specific numbers for the movement's Belgian membership, information for certain years can be garnered from letters and other documents ${ }^{18}$. Such information, despite being incomplete, nonetheless offers an indication about the number of members in Belgium, the movement's local evolution, and, more importantly, the relative strength of the different kinim during this time period (Table below).

\begin{tabular}{|c|c|c|c|c|}
\hline \multicolumn{1}{|c}{ date } & \multicolumn{1}{c}{$\begin{array}{c}\text { ken in } \\
\text { Antwerp }\end{array}$} & $\begin{array}{c}\text { ken in } \\
\text { Brussels }\end{array}$ & \multicolumn{2}{c|}{$\begin{array}{c}\text { ken in } \\
\text { Liège }\end{array}$} \\
\hline 1933 & 106 & 107 & $/$ & 213 \\
$1935-1936(?)$ & 110 & 60 & $/$ & 170 \\
1938 & 140 & 100 & 30 & 270 \\
1940 & 160 & 90 & 20 & 270 \\
1942 & 130 & $?$ & $?$ & $?$ \\
\hline
\end{tabular}

As previous table evidences, the movement continued to grow in Belgium from 1933 until the beginning of the war. Data could not be found for prior to 1933, most likely because the movement's early history was characterised by great turmoil, internal crisis and instability. The movement was still consolidating itself, during which time it experienced a great number of defections (to the communists)among its leadership ${ }^{19}$. In Antwerp there appears to have been constant growth throughout this period, whereas in Brussels membership tended to fluctuate. The reason for these fluctuations must be sought in the stark competition which the Brussels Hashomer Hatzair faced from left-wing Jewish organisations. Brussels had a stronger Jewish (and

\footnotetext{
${ }^{18}$ Archive Ein Hakhoresh, Hagarin habelgi, Hashlama Belgit 1932-1993, Letter to the Garin in Erets Israel; Yad Yaari, (4)2.11-2, handwritten report to hanhagah elyonah; Central Zionist Archives (CZA), Z4/30352, Report of the Zionist Youth Federation; L'Avenir juif, 194, 1940 ; Moreshet, D.1.1171-75, Letter Dougi Donner to Arthur Rath.

${ }^{19}$ Yad Yaari, (5)1.1-34, Report of the Lishkat Hakesher.
} 
zionist) leftist orientation, as opposed to the more liberal and religiousminded zionist movement in Antwerp. Another aspect highlighted by Table 1 is that the ken in Antwerp was by far the strongest Shomerorganisation in Belgium. This is also confirmed in the sources and by various testimonies of older members ${ }^{20}$.

The Hashomer Hatzair held a strong position among the various Zionist youth movements in Belgium. With its 270 members it was one of the country's leading Zionist movements. In 1938, for instance, the religious zionist youth movement Bne Akiva counted 250 members and Dror, the youth movement of the Poale Zion-Tseirei Zion,counted another 250 members $^{21}$.

Among the various zionist youth movements the competition for the hearts and minds of the Jewish youth was intense. The Hashomer Hatzair actively sought to recruit members from other movements into its ranks, with varying degrees of success ${ }^{22}$. Yet, while competition between the movements may have been overzealous, the relations between the various youth movements were cordial. Invitations were extended for each other's festivities and shared sports events were organised. From 1937 most zionist youth movements were organised into a federation, the zionist Youth Federation, which arranged lectures, activities and educational activities ${ }^{23}$. Hashomer Hatzair even enjoyed a more or less cordial relation with Betar, the youth movement of the right-wing Revisionist Party and a staunch ideological adversary, though there were intense debates between them and at least one source mentions street scuffles and disturbances of each other's meetings ${ }^{24}$.

Outside the Belgian zionist community, the Hashomer Hatzair experienced staunch competition from the Jewish section of the communist party and Jask, the youth organisation under its influence. Due to its extreme left-wing ideology, the Hashomer Hatzair movement was particularly prone to defections to the communists. The combination

\footnotetext{
${ }^{20}$ Cegesoma, Interview with Donner David,00073-00074.

${ }^{21}$ Yivo, David Trocki,Files RG 235, Folder 17 A-B.

22 Yad Yaari, (5)1.1-34 (1930-1933);Interview with Rachel Beckmann (maiden name : Lederman), 12.01.2014.

${ }^{23}$ ''Avenir juif, 42.

${ }^{24}$ Cegesoma, Interview with Donner David, 00073-00074.
} 
of an essentially internationalist marxist ideology and zionism (by definition a nationalist movement) resulted in certain inconsistencies and paradoxes in the movement's ideology. This, combined with the reality on the ground, both in Belgium and in Palestine, led some members to become fully fledged revolutionaries instead of pioneers in Palestine. The economic crisis and its repercussions on the Jewish population also led members to become more involved in trying to improve the situation of the "Jewish proletariat" rather than investing time and energy towards establishing a homeland in Palestine. As noted, in the initial period a sizable part of the Hashomer Hatzair leadership left Antwerp and became some of the leading figures in the Jewish section of the Belgian Communist Party ${ }^{25}$. Later on, members continued to trickle into the ranks of the communists.

The biggest obstacle for the Hashomer Hatzair was not competition from other youth movements, however, but rather the high demands and expectations with which the movement burdened its members. The Hashomer Hatzair required full and unwavering commitment from its members towards fulfilment of the movement's goals. To attain these goals, the movement went to great lengths : guidelines were established which regulated the members' conduct, values, worldview, relations between the sexes, education (even choices of higher education) and political views, and the members were expected to comply. Members were also obliged to follow all instructions and commands of the movement, including such measure as the call to go to hakhsharah. All of this required a high degree of individual commitment, and this was often a stumbling block in the integration of new members who could not or would not meet the requirements set forth by the movement. One result was that within the membership of the Hashomer Hatzair there developed a view that they were a kind of moral and political vanguard on the brink of great achievements, and this instilled a kind of elitist character in the movement.

Although the movement required much of its members, it nonetheless remained quite democratic. The leaders were elected, and, despite the strong emphasis on the movement's communal aspects, individual self-education and reflection formed a cornerstone of the movement's

${ }^{25}$ R. Van Doorslaer, Kinderen..., op. cit., pp. 76-81. 
ideology. Discussions were common and were freely held, and internal criticism of the movement was acceptable. It is also important to consider that the period of the 1930 's was in general characterised by radicalisation within parties and ideologies, both inside and outside the Jewish community, and the Hashomer Hatzair was not an exception in this respect.

The extreme left-wing and zionist ideology of the movement, combined with the alternative value system that it sought to implement, caused much friction and anger between parents and their children who, often against their parents' will, had joined the movement. The movement was regarded as a radical "communist" movement and the unfettered attitude that prevailed between its girls and boys was a further source of consternation. These frictions also formed part of the wider generational struggle in Jewish society at that time.

The vast majority of the Hashomer Hatzair members were from immigrant backgrounds (primarily from Poland). Some were second generation immigrants, and thus sometimes had the option of acquiring Belgian citizenship at age sixteen; most members, however, were first generation-immigrants from Eastern Europe. At a later stage, the movement also attempted to recruit from the wave of refugees from the German Reich and Austria. Although most members were from Poland or elsewhere, the language spoken in the youth movement during discussions and used in its various papers and periodicals was the local Antwerp dialect of Dutch. Amongst each other, members switched freely between languages, and various surviving correspondences are in Dutch, German, French, Yiddish and Hebrew. Various members had some knowledge of Hebrew, but most knew only the rudimentary basics and were more familiar with the Yiddish of their "home countries".

While there was some diversity in the socio-economic profile of the movement, especially in the early period, most of the members were from working-class families. Members who were old enough to work often laboured in the traditional Jewish sectors of the economy. In a report of the hanhagah mekomit to the hanhagah elyonah the author outlines the professions amongst the majority of the older members. In Brussels, the men were employed in leather and fur manufacture and 
cardboard production. In Antwerp, the majority of the men worked in the diamond industry as lower paid semi-industrial diamond cutters. The women often worked as seamstresses and in factories ${ }^{26}$. While there was certainly greater diversification in the professions occupied by the members - some were even sent to agricultural schools for higher education - the report nonetheless gives a clear indication as to the social background of the members. A small minority within the movement were from well-to-do families.

\section{Activities of the movement}

The three main components of the Hashomer Hatzair's activities consisted of educational activities, activities promoting zionism and scouting activities.

\section{Educational activities}

In the sources, the word "cultural work" is often used to describe educational activities. This work consisted of various elements aimed towards the same goal, namely, the education of a new generation of shomrim according to the values set forth by the movement. These activities corresponded closely to the principle of hagshamah (selfrealization), one of the cornerstones of the Hashomer Hatzair. Hagshamah is the individual commitment of each member to live according to the values and ideals of the Hashomer Hatzair, with the ultimate goal of making aliyah and living in one of the movement's kibbutzim. The educational activity of the movement was thus directed towards creating a generation of young people who would establish a new State in Erets Israel on a socialist model.

This principle was taken quite seriously. The hanhagah elyonah, in cooperation with the hanhagah rashit, made a detailed list of topics and subjects of education for each age group. Bibliographies were compiled of books which members were expected to read. The range of these topics was notably broad, and included Jewish national history, biographies of leading Zionist intellectuals, Jewish writers and philoso-

${ }^{26}$ Yad Yaari, (4)2.11-2,Handwritten report to the hanhagah elyonah. 
phers, geography of Palestine, physics, mechanics, geography (especially of Palestine), biology, anatomy, cartography, political science and political theorists (mostly socialist), sociology, psychology, pedagogy, arts and culture ${ }^{27}$.

These subjects were often taught by members. They would prepare a discussion (sikhah) on a certain topic (presumably given by the instructor's madrikh) and give a short speech to the rest of the kvutsah or plugah. These discussions were then later entered into a kvutsah booklet, a small booklet in which the activities of a kvutsah were documented. In addition, each member was required to have a Sefer Hakria, a booklet in which he or she recorded short summaries (along with commentary and criticism) of their required readings ${ }^{28}$.

All Hashomer Hatzair members were required to learn Hebrew. As in other zionist youth movements (except Yung Bor, the youth movement of the Yiddish-speaking Linke Poalei Tzion), learning Hebrew was seen as a crucial endeavour. Hebrew was to be the language of the new, strong Jew, who would live in mental and physical harmony in the soon to be established Jewish National Home. Conversely, Yiddish was regarded as the language of the diaspora and its affiliated persecutions and perpetual calamities. It was held to embody the old, weak Jew, who was at the mercy of others, and the language itself was downplayed as being no more than a mixture of German, Slavic and Hebrew influences. In short, Hebrew was the future, Yiddish the past. The young members of Hashomer Hatzair learned Hebrew through songs and basic sentences. The older members attended classes organised by the movement or, later on, by other zionist institutions and circles. Although Hebrew was of central importance to the movement, it was not readily spoken amongst the members and only a few mostly older bogrim - were actually fluent ${ }^{29}$.

Hashomer Hatzair was a strictly secular organisation, though it did maintain certain aspects of religious culture and tradition. Jewish festivals were celebrated, although in a decidedly different fashion than in traditional circles. Certain books of the Tanakh, like the Prophets,

\footnotetext{
ה-2.4

${ }^{28}$ Yad Yaari, (5)2.11-2, Folder 1 ;self- written Iton.

${ }^{29}$ Yad Yaari, (4)2.11-2, Handwritten report to the hanhagah elyonah.
} 
were a source of inspiration for the movement and were read and analysed. Jewish history was studied as it was recorded in the Scriptures. Hashomer Hatzair approached religion as a cultural framework, from which it highlighted certain aspects in shaping the movements identity. Strict adherence to religious law and customs was regarded as something archaic and of the old generation. Nonetheless, the movement opposed assimilation and strongly rejected assimilated youth who had lost connection to the Jewish past; instead, the movement sought to infuse its members with a strong secular-orientated Jewish identity.

\section{Promoting zionism}

While the movement's educational program was thus directed towards members' self-realisation, there was also a more practical aspect in its activities : namely, the advancement of zionist goals. Zionism, next to marxism, was one of the pillars upon which the movement rested; moreover, compared to other zionist (youth) movements in Belgium Hashomer Hatzair took a radical approach towards the Jewish question. The movement entirely rejected any political or social work in the galuth (diaspora) that might divert its members' time and energy from the goal of settling in Erets Israel. Other zionist movements in Belgium in the 1930's, though remaining committed to zionist ideals, made efforts to aid refugees coming to Belgium from Germany and Austria and to improve the situation of impoverished Jewish immigrants in Belgium. For the Hashomer Hatzair there was no doubt that a sustainable solution to the Jewish question was to be found only in Erets Israel. Anything that distracted from this goal was considered futile and merely a palliative for the real solution.

The Hashomer Hatzair strongly engaged in activities for the advancement of the zionist cause, primarily, in the diaspora, by collecting funds for the KKL, the Jewish National Fund. The journals of the KKL include lists of the contributions from each zionist youth move- 
ment and organisation ${ }^{30}$. Together, the zionist youth movements collected over 20\% (155.203 Belgian Francs) of the KKL's total revenue for 1937-1938. This evidences the industriousness and dedication of the youth movements ${ }^{31}$. The Hashomer Hatzair, in particular, was often praised by the KKL for its staunch commitment.

\section{Scouting Activities}

The third component of the movement's activities concerned scouting and physical activities. Every Sunday, the groups gathered for tiulim (trips). These consisted of walks in the countryside or, when adverse weather prevailed, cultural activities. The members were instructed in basic scouting skills (including learning Morse code, map reading, knot tying, first aid, orientating by the stars and compass) and learned about the history of scouting 32 .

In the summer, a makhaneh, (camp) was held, which lasted around two weeks. These camps were organised by age group, and members from the Hashomer Hatzair in Antwerp and in Brussels and later in Liège attended the same camps. These camps were held in the Ardennes, the Vosges, and the Grand Duchy of Luxembourg, and included scouting activities, day marches and cultural activities ${ }^{33}$. Besides being a welcome reprieve from the hard work conducted during the year, the makhaneh also served as a kind of experiment in communal life for the members. It was also a period of recreation and respite, when the members could enjoy games, marches and activities, albeit sometimes to the chagrin of more zealous members and leaders, who often lamented the apparent lack of ideological and communal work amongst certain members in the makhaneh ${ }^{34}$.

Sometimes kvutzot from France, Switzerland, and Germany also joined the summer camps in Belgium. After establishment of the lish-

\footnotetext{
30 The Journal of the KKL for the years 1928-1933 are kept in the Central Zionist Archives (CZA), PR/1143/1. Some reports and documents of the KKL in Belgium from 1926-1940 are held in Yivo, David Trocki files, RG 235, Folder 17 A-B.

${ }^{31}$ Yivo, David Trocki files, RG 235, Folder 17 A-B (Keren Kayemet, Keren Hayesod).

${ }^{32}$ Moreshet, D.1.6326-03, Kvutsah booklet.

${ }^{33}$ Yad Yaari, (5)3.11-2, letter concerning the organisation of summer camps.

${ }^{34}$ Yad Yaari, (3)2.11-2, Folder 10, self written plugah booklet.
} 
kat hakesher (liaisons office), in 1930, members from Tunisia came to Belgium to partake in joint summer camps. The lishkat hakesher organised the various histadruth (organisations) of Belgium, France, Tunisia, Holland and later Egypt in an official framework which included shared educational material, publications, etc $^{35}$.

\section{Hakhsharah and aliyah}

While a member's overall life within the movement was directed towards the specific goal of making aliyah and living in a kibbutz, the actual preparation for these steps took place only when the member had reached a certain age. The bogrim, the oldest age group in the movement, were those who had received the call from the movement to commence hakhsharah (preparation); this happened when they reached the age of twenty. Some of the bogrim (a minority, in fact) who wished to study further were sent by the movement to technical or agricultural schools, such as the Institut agricole de l'État in Gembloux $^{36}$. The movement strongly emphasised practical studies; "bourgeois studies" (like law and economics) at university were prohibited. This emphasis on manual work corresponded closely with the ideology of the movement, particularly its aim of establishing a Jewish working class in Israel and an agricultural base there in the form of the kibbutzim. Education thus was aimed at acquiring practical skills which met the goals of the movement and which would be useful in the future.

Most bogrim, however, did not receive their practical skills via higher education; rather, they gained valuable insights into agrarian life by spending time at a hakhsharah centre. All bogrim were expected, even obliged, to at some point go on hakhsharah and prepare for their future life in a kibbutz. The most common form of hakhsharah was called hakhsharah khaklait (agricultural hakhsharah). Members, individually (hakhsharah bodedet) or in groups (hakhsharah kibbutzit), were sent to work on the land of Belgian farmers, and later in specialised centres, where they learned to plough, sow and work with cattle and poultry. In 1927, three years after the establishment of the movement

\footnotetext{
${ }^{35}$ For information about the Lishkat hakesher, see : J.Stamberger, op. cit., pp.57-60.

36AJHA-SB, Audio-704.
} 
in Antwerp, the first members of the organisation went on agricultural hakhsharah $^{37}$.

In the initial period (about 1927-1930), members of Hashomer Hatzair in Belgium went on hakhsharah in the Netherlands, as there were no viable options for agricultural training in Belgium. The Netherlands was home to the Association for the Professional Training of Palestine Pioneers (Vereniging tot vakopleiding van Palestina-Pioniers), which had its headquarters in Amsterdam but was based in Deventer $^{38}$.

The Hashomer Hatzair initially dealt with the issue of hakhsharah on its own. In 1929 it established the Hekhalutz movement in Belgium $^{39}$. This was the umbrella organisation of the youth movements of labour zionism, and was responsible for the work and training of the pioneers in the diaspora.The Hekhalutz was supported by all labour zionist parties and most of their youth movements ${ }^{40}$. In Belgium, it seems that the Hashomer Hatzair, the oldest of the labour zionist youth movements in the country, was the main instigator for establishment of the Hekhalutz. Later, other labour zionist youth movements, like Dror, Gordoniaand Maccabi Hatzair,together with nonaffiliated youths known as Stam Khalutz, joined the organisation. In 1939 the Hekhalutz counted 150 members in Belgium ${ }^{41}$. At the end of the 1930's, Yung Bor, the youth movement of the Linke Poale Tzion, also joined the Hekhalutz after the Linke Poale Tzion joined the Zionist Federation ${ }^{42}$.

In 1934, a Hekhalutz centre was established in Villers-la-Ville, near Nivelles, in the centre of Belgium. The centre was subsidized by the Zionist Federation in Belgium and the Organisation of Zionist women (WIZO), and afforded a location where members of the various organisations could go on hakhsharah ${ }^{43}$. In this centre, as well as in the He-

\footnotetext{
${ }^{37}$ Yad Yaari, (5)2.11-2, Folder 3, Journal Hashomer Hatzair,nr 2, p. 2.

${ }^{38}$ Yad Yaari, (5)1.11-2, Folder 3 ; E.H., Etzlenu, p. 22.

${ }^{39}$ Yad Yaari, (5)2.11-2, Folder 3, Journal Hashomer Hatzair,nr 2, p. 2.

${ }^{40}$ W. Laqueur, AHistory of Zionism, New York, 1972, pp. 326-328.

${ }^{41} L^{\prime}$ Avenir juif, nr 175, 20.10.1939.

${ }^{42}$ H. Wagman Eshkoli, « The contacts between the World Hachalutz Center in Geneva and the Zionist-Pioneering Underground in Belgium », in D. Michman (ed.), op. cit., Jerusalem, 1998, p. 398. According to the author by 1940, the hekhalutz in Belgium counted 215 members.

${ }^{43} L^{\prime}$ Avenir juif, nr 55 and nr 175.
} 
khalutz organisation, things did not always proceed smoothly, as the different youth movements did not always share concurrent views. The Hashomer Hatzair, with its numerical strength, appears to have had much influence within the organisation ${ }^{44}$.

Life at hakhsharah was not easy for the members. They had to work long hours doing occupational work which they were generally entirely unfamiliar with. All members of Hashomer Hatzair were from Belgium's large cities and were usually unaccustomed to the hardscrabble life that prevailed in rural areas of Belgium. As mechanisation (such as tractors and milking factories) in agrarian life had not yet been introduced on a large scale, everything had to be done manually. The hakhsharah centreoccasionally experienced a lack of resources, especially in winter, when the farmers did not need assistance; at such times conditions in the centre became notably harsh.

Members were officially expected to stay for one year on hakhsharah, though this did not always occur. Some members went for a few months; others dropped out after a month. Some members, however, stayed for up to two years.

Besides agricultural hakhsharah, there was also a form of hakhsharah known as hakhsharah ironit (City hakhsharah). This type of hakhsharah consisted of a group of bogrim living together as a commune in an apartment or house in a city, where they pooled their incomes from the jobs they worked. Such a commune was sometimes referred to as a kibbutz. The first so-called kibbutzironi was established in 1933, in Brussels ${ }^{45}$.

It appears that hakhsharah ironit sometimes served as a substitute for collective agricultural hakhsharah in times when the latter was impossible or exceedingly difficult to organise. In 1933, for instance, a kibbutz was organised in light of the major difficulties in organising a collective agricultural hakhsharah during the economic crisis. Farmers looked upon the Jewish youth as strangers and there were no possibilities for the establishment of new centres. Only individual agricultural hakhsharah was possible, and these did not fulfil the need for commu-

\footnotetext{
${ }^{44}$ Yad Yaari, (4)2.11-2.

45Yad Yaari, (1), ה-19.04. folder 2, Report Lishkat Hakesher toHanhagah Elyonah,
} 
nal life. It was therefore decided to organise a hakhsharah ironit for the preparation for collective life of the members of the garin $^{46}$.

This also occurred during the German occupation, when a kibbutz consisting of several bogrim was set up in Antwerp, at the apartment of Mottek Adler, one of the leaders of the movement in Antwerp ${ }^{47}$.

One remarkable form of hakhsharah which, as far as known, was undertaken only in the first period, in the late 1920 's, was that of an industrial hakhsharah. Members from both the ken in Brussels and Antwerp, wishing to familiarise themselves with the proletarian conditions that prevailed in Belgium, went to work in the heavy industries in the suburbs of Brussels and in the glass factories in Antwerp. A group of bogrim from Antwerp even worked for a month in the coal mines in the Borinage; this was done without the knowledge of their parents, whom the members had told that they were going on vacation $^{48}$. The members who went to work in these factories were indeed confronted with the life of the Belgian proletarians, and upon returning to the cities the majority of them defected to the Communist Party.

The fact that this atypical form of hakhsharah took place in the early period of the movement in Belgium is not surprising. As previously mentioned, the first years of the movement in Belgium, up to around 1930, were characterised by turmoil and instability.

Whilst preparing for aliyah was relatively easy, due especially to the well-organised institutions in Belgium, the actual journey to Palestine was an entirely different matter. The easiest way to make aliyah was by obtaining an « immigration certificate » issued by the British Mandatory Government to the Palestine Office, the organisation of the Jewish Agency responsible for distribution of the certificates and the organisation and regulation of Jewish immigration to Palestine ${ }^{49}$. In Belgium, there was a Palestine Office in Brussels.

However, these certificates were scarce. The British government, due to the difficult political situation in the Mandate territory (where

\footnotetext{
46 Ibid.

${ }^{47}$ Moreshet, D.1462, letter Austriak (Yeshayahu Ostri-Dan) to Kibbutz Artzi, p. 5 ; Cegesoma, interview with Donner David, 00073-00074.

${ }^{48}$ Archives Ein Hakhoresh, Etzlenu, p. 22.

${ }^{49}$ « Palestine Office », inM. Berenbaum - F. Skolnik (eds.),op. cit., p. 595.
} 
Arab resentment over Jewish immigration was widespread), imposed restrictions on Jewish immigration and issued quotas for how many Jewish immigrants would be allowed into the area each year. The Palestine Office decided how many certificates each country would receive and, after the nazi takeover of Germany in 1933 and the $\mathrm{An}$ schluss, or annexation, of Austria in 1938, favoured people of these nationalities, as their need was considered to be the highest. The number of certificates for Belgium was therefore limited; moreover, the certificates were distributed between the various zionist circles, youth movements and private individuals. This meant that the Hashomer Hatzair could hope to receive only two or three certificates each year, though demand vastly exceeded this.

For the Hashomer Hatzair, whose entire ideology revolved around the commitment of each member to live in a kibbutz in Erets Israel, this situation was untenable. The movement therefore sought options to circumvent these restrictions.

One such solution, apparently practiced only in the late 1920 's, involved organising fake marriages between members. Any male member who received a certificate was allowed to take his wife with him, and so the movement arranged fake marriages in order to facilitate additional departures to Palestine ${ }^{50}$. It is not known whether this practice continued into the 1930's.

The most common strategy by which the Hashomer Hatzair circumvented the restrictions was illegal immigration, the so-called aliyah beth, in which members left for Palestine without certificates and resided in the kibbutzim illegally. There were risks involved with this, however; if apprehended by the British Royal Navy, members would be sent back to Europe or - later, after the war - incarcerated in detention camps in Cyprus and Palestine.

The first shomrim (members of Hashomer Hatzair) from Belgium to make aliyah departed in 1929. These members drifted apart and ended up in various kibbutzim throughout Palestine ${ }^{51}$. The first group to stay together as a garin in Erets Israel departed in November 1932. This group was preceded by three members who left in 1931 and served as a

\footnotetext{
${ }^{50}$ Cegesoma, interview with Ruchla Ekstein, AA 2268/337.

${ }^{51}$ Ibid.
} 
base to guide the others to the kibbutz in the town of Khaderah. This group, known as Garin Aleph, numbered eighteen members from the ken in Antwerp and in Brussels. The entire emigration process was carefully organised: scouting uniforms (from Belgian scouts) were acquired through an intermediary, and the plan was to pose as a Belgian scout group on a tour in the Middle East. The group set out for Lebanon, then under French Mandate, and from there managed to cross into Palestine without detection and settle in a Kibbutz in Khaderah $^{52}$. This garin later helped to establish kibbutzEin Hakhoresh.

In the meantime, emigration from Belgium continued, both legally (via the scarce certificates) and illegally. By 1934, the first four members of Garin Beth joined Kibbutz Mizra ${ }^{53}$. More members followed and Garin Beth decided to search for a younger kibbutz; they thus settled at kibbutzDan, in the north of the Mandate Palestine ${ }^{54}$.

It appears that, in all, during the period from 1931-1948 between 50 and 100 members of Belgium's Hashomer Hatzair immigrated to Palestine. Some remained in the kibbutzim of the movement; others, over time, went to live in the cities or, when unable to sufficiently adapt, returned to Belgium ${ }^{55}$.

The reason for this relatively high number of "defections" was due to the stark, difficult life in Palestine during the 1930's and 1940's. Upon arrival, members faced a trying period of adaptation. The climate conditions and new surroundings were entirely different than those of Western Europe. Around Khaderah the mosquito-infested marshlands caused malaria and other diseases. The economic conditions prevailing in the kibbutzim and in the yishuv as a whole were far less developed than in Belgium, and the standard of living was much lower than what had been known in Antwerp and Brussels.

\footnotetext{
${ }^{52}$ Archives Ein Hakhoresh, Etzlenu, p. 3.

${ }^{53}$ Yad Yaari, (4)2.11-2, report to Hanhagah Elyona.

${ }^{54}$ Yad Yaari, (1)3.11-2, Folder 2, letter from Regina in Givat Hashomer to Pitah in Antwerp (17.11.1936).

${ }^{55}$ In the archives of Ein Hakhoresh we found a list of members from Belgium who immigrated to Israel and stayed in the different kibbutzim of the movement. This list must have been compiled somewhere in the 1960 's and only includes the people who at that point in time still lived in the kibbutz. The ones who had returned to Belgium or settled in the cities are not included. The lists give 47 persons of the ken of Antwerp and Brussels who made aliyah in the period 1932-1948.
} 
Furthermore, some members simply could not adapt to the kibbutz system and its strict communal life. Everything in the kibbutz was the shared property of the commune, from the houses to the clothes, and even the wages. The children did not reside with their parents; instead, they lived in communal fashion, in children's houses, and were taken care of by metaplot (nurses). The agrarian work in the orchards and fields of the kibbutz was also quite demanding. Tensions between the Arab and Jewish populations further complicated (and sometimes endangered) the lives of the members.

The political situation prevailing in British Mandate Palestine did not correspond with the ideological visions propagated by the Hashomer Hatzair. The movement argued for close cooperation between the Arab and Jewish labourers, each of whom the movement regarded as being oppressed by the forces of the vested interests : the Jewish labourer by the Jewish bourgeois capitalist, the Arab fellah by the Arab feudal landowner. In this view, the Jewish capitalists and the Arab feudal landowners were being protected and supported by the British colonial authorities. The Hashomer Hatzair argued that Arab and Jewish labourers should stand together against these reactionary forces; moreover, they advocated for a binational constitutional state in which both peoples could live in peace and prosperity ${ }^{56}$.

The reality, however, was totally different from the ideological vision of the Hashomer Hatzair. Periods of relative calm in British Mandate Palestine were followed by periods of fierce interethnic violence $(1921,1929,1936-1939)$. That widespread Arab discontent resulted not from class struggle but was in fact fuelled by nationalist aspirations could not, or would not, be recognised by the movement. Such an assessment of the political situation would have been directly opposed to the nationalist aspirations of the zionist movement. According to the Hashomer Hatzair the reasons for the Palestinian-Arab struggle were due to manipulations from outside forces. On one hand, fascist infiltrators, seeking to cause trouble in Britain's imperial possessions, inflamed Arab public opinion; on the other hand, the British

${ }^{56}$ E. Margalit, op cit, p. 46. 
colonial power, keen to apply the old tactic of divide and rule, set the communities against each other ${ }^{57}$.

Even as Hashomer Hatzair kept to its ideology and urged for greater cooperation between Arabs and Jews, the members also adapted to the realities of the situation. Many members of the Hashomer Hatzair joined the semi-official Jewish Haganahmilitiaand its elite force, the Palmakh. Weapons were cached in the movement's kibbutzim, and training and communication centres for the militia were established there.

\section{The movement during and after the occupation of Belgium}

After the outbreak of the Second World War in Belgium, in May 1940, Jewish life in Antwerp came to a standstill. A great number of Jews fled the city and tried to find safety in France or, if possible, in other countries. Immediately after the start of the German offensive, the hanhagah mekomit of Antwerp organised a council at which the older members would determine the movement's course of action. It was decided that the histadruth would continue to function and that female members would assume the leading functions, as it was likely that any males older than 16 would soon be mobilized ${ }^{58}$. A few days later, however, as most of the Jewish population of Antwerp, including most of the younger members, were leaving the city, the leadership opted to take matters into its own hands. Instead of watching the ken slowly disintegrate, it was decided to formally disband the movement, and by the $14^{\text {th }}$ of May all members had left the city.

Immediately after the outbreak of the war, leaders of the ken in Antwerp destroyed the archives in the movement's headquarters so that this valuable information would not fall into German hands. They then went to the house of one of the leaders of the hanhagah rashit, Natan Dubinsky, where the archives of the hekhalutz were kept, and burned them ${ }^{59}$. Dubinsky was arrested by the Belgian State Security the same morning, probably because he was suspected of having

\footnotetext{
57Yad Yaari, (3)3.11-2, self written Itonim, 3, « Feiten en gebeurtenissen ».

${ }^{58}$ Moreshet, D.1.5024, leadership log of Freddy Spielman.

${ }^{59}$ Moreshet, D.1.1171-75 and Ghetto fighters house (Beit lohamei hegetta'ot), File : Belgium, 9 , Bericht über die Belgische Tnuah.
} 
questionable loyalties as a foreign national. He was sent to a French detention camp, from which he managed to escape in $1941^{60}$.

After the ken was disbanded, a group of older shomrim from Antwerp and Brussels (22 people in all) gathered in Koksijde, a small town on the southern part of the Belgian coast, at the summer home of the parents of a member from a wealthy background ${ }^{61}$. Initially, the group attempted to cross the border into France, but upon seeing the situation at the border, where thousands of Jews were being delayed without any food, water or shelter and prevented from crossing the frontier, the members decided to return to Koksijde.

Thereafter they attempted to find a way to cross the Channel to England, from which they hoped to then be able to make aliyah. They sent a telegram to London, presumably to the zionist headquarters, urgently requesting certificates. After receiving no reply, they began looking for a boat which could get them across the Channel, but this plan had to be aborted at the last minute ${ }^{62}$. During their time in Koksijde, the group organised as a kvutsah and engaged in cultural activities; they held discussions (sikhot), talked about zionist and Jewish history, and analysed current events and their implications for the movement. Later, a small group from the religious zionist youth movement Bne Akiva joined the kvutsah at the summer home. From the very beginning of the war, the Hashomer Hatzair sought possibilities for making aliyah; this search would continue throughout the war.

After the initial hostilities had ended (on 28 May 1940), leaving Belgium firmly under German control, most of the members $(90 \%$ of them) returned to Antwerp. Almost immediately, the Hashomer Hatzair reorganised the ken. On June $5^{\text {th }}$ and $6^{\text {th }}$, assemblies were held with the leadership, during which the future course of the movement was debated. This was not without risk, as such a "mass gathering" of a zionist marxist organisation would certainly have attracted negative attention from the occupying German forces. It was decided to opt for various safety measures. The movement's Antwerp meeting hall, in Marinus Street, was closed; members were instructed not to gather in

\footnotetext{
${ }^{60}$ Moreshet, D.1462, letter Yeshayahu Ostri Dan, p. 1.

${ }^{61}$ Ibid., p. 2.

${ }^{62}$ Cegesoma, interview with Donner David, 00073-00074.
} 
large groups, and any activities that involved larger groups (gdudim, plugot) were suspended. All activities would henceforth take place within each kvutsah, with the madrikh responsible for the education of the members. The meetings of the kvutsot would be held in the apartments of older members or in parents' houses ${ }^{63}$.

Scouting activities became nearly impossible, and the emphasis was redirected to cultural and educational matters. The new conditions, combined with the fact that the organisation was disconnected from the movement's world centre and from Hashomer Hatzair organisations in neighbouring countries (and thus did not receive news about the overall movement), resulted in a tense and nervous atmosphere. The leadership tried to create a sense of normality through developing educational schedules and resuming activities when possible; nonetheless, due to the need for discretion and secrecy there seemed to be much uncertainty in the movement's ranks.

This uncertainty led the movement to organise a bogrim conference (kinus bogrim), at which all topics would be discussed. On the 28 July 1940, over forty members, mostly from the ken in Antwerp but also some from Brussels, attended a conference, where discussions were held and lectures given. A small minority of the members argued that, given the current situation, the Hashomer Hatzair should align itself with the revolutionary forces in the International Labour Movement and join the Komintern and the communists. The majority of the members, however, argued that the current situation reinforced and proved the justness of the zionist solution to the Jewish question. According to this view, in the diaspora, there could be no normal life for the Jewish people and only Palestine could absorb the Jewish masses after the war. It was decided that possibilities for aliyah should be sought and that the movement should continue to follow its zionist course $^{64}$.

In the meantime news had begun to arrive, via members who had fled to Marseille at the outbreak of the war, of possibilities for making aliyah. At the beginning of August 1940, two members (Mordechai "Mottek" Adler and Numa Eisenzweig) were sent to investigate these

\footnotetext{
${ }^{63}$ Moreshet, D.1462, letter Yeshayahu Ostri Dan, p. 4

${ }^{64}$ Ibid., pp. 5-7.
} 
possibilities. They spent five weeks on the road, after which Eisenzweig returned to Belgium with the positive news that there were indeed prospects. The movement set out to organise small groups of older members (bogrim, tsofim bogrim) who would travel to Marseille. After the first such group had departed, troubling news was received. Mottek Adler, who had stayed behind in Marseille, informed the group that Marseille'sbeaches were guarded and that as of yet no ship had left for Syria or Lebanon. Following this news, the members returned to Antwerp ${ }^{65}$. Yet another attempt at making aliyah had failed.

In the autumn of 1940, the situation of the Jews in Antwerp began to deteriorate severely. The first "Jewish decrees" were published, which eroded not just the rights Belgium had always bestowed on its citizens but also basic rights it had bestowed on foreigners. The decrees also legally differentiated Jews from gentiles. The first steps were taken to destroy Jewish economic life; such steps included barring Jews in Belgium from certain professions and occupations. Ensuring an income became problematic; there had been food shortages at the beginning of the occupation, but now the situation became increasingly desperate and numerous products could be found only on the black market and at very high prices.

It was during this period that Hashomer Hatzair, together with other zionist youth movements like Bne Akiva, became active in social welfare matters, and thereby in practice, if not in principle, shed its rigid refusal to work in the galuth (diaspora). In 1941 and 1942, Hashomer Hatzair and Bne Akiva members went to work in the countryside, where they collected agricultural products and distributed them to those most in need in the community ${ }^{66}$.

With the creation of the Association des Juifs en Belgique (AJB, Association of Jews in Belgium) on the orders of the German authorities at the end of 1941, all Jewish movements were ordered to be disbanded or to be merged with the AJB. Only athletic clubs were allowed to function independently. In response, all zionist youth movements continued to operate, but under the cover of the Maccabi Hatzair Sports Club. It appears, however, that relations between Hashomer Hatza-

\footnotetext{
${ }^{65}$ Ibid., p. 7; Cegesoma, interview with Donner David, $\mathrm{N}^{\circ} 00073,00074$. ${ }^{66}$ D. Michman, op. cit., p. 388.
} 
irand Maccabi began to deteriorate during this time. This may have been the result of tensions that had evolved within the Maccabi Hatzair organisation due to the youth movements formally joining it despite maintaining their own political allegiances. Furthermore, the AJB favoured Maccabi Hatzairand gave it preferential treatment. This led some movements to leave the organisation and continue their activities illegally in other locations ${ }^{67}$.

While the hakhsharah centre in Villers-la-Ville was shuttered in early 1942, a new option for hakhsharah became available through the Israelite Community of Brussels (Communauté israélite de Bruxelles), which had established an agricultural farm in Bomal in 1941, intended primarily for German and Austrian refugees ${ }^{68}$. This farm was later taken over by the AJB. Members from zionist movements of all political persuasions, religious and secular alike, attended the hakhsharah. According to Dan Michman, more than sixty khalutzim, mostly from Hashomer Hatzair, worked in the surrounding fields ${ }^{69}$. After the Germans began deporting Jews from Belgium to the East, the centre was closed, as the members had received information that they were to be deported.

Whereas agricultural hakhsharah was possible again only around the beginning of 1942, a hakhsharah ironit or kibbutz was set up immediately after the reorganisation of the ken in Antwerp. This was undertaken by several bogrim who lived as a garin in the apartment of Mottek Adler. This commune had an important function, as it served as a meeting hall for the movement's leadership and offered a moral and educational example to the rest of the organisation that the ideal of collectivity could be realised even during the most difficult of times ${ }^{70}$.

In late 1941 and early 1942, the Jewish community in Antwerp was rife with rumours about the deportation of the Jews from Belgium. In the meantime, the Hashomer Hatzair, whose leaders had re-

\footnotetext{
${ }^{67}$ Ibid., p. 389.

${ }^{68}$ B. Dickschen, « La ferme-école juive de La Ramée durant l'Occupation (avril 1941-août 1942) », in Cahiers de la Mémoire contemporaine, nr 6, 2006, pp. 79-133.

${ }^{69}$ D. Michman, op.cit., p. 390 ; according to Wagman-Eshkoli however, 120 khalutzim (pioneers) were trained at Bomal : H. Wagman Eshkoli, op. cit., in D. Michman (ed.), op. cit., p. 400.

${ }^{70}$ Moreshet, D.1462, letter Yeshayahu Ostri Dan, p. 5 ; Cegesoma, interview with Donner David, 00073-00074.
} 
established contacts with the Hashomer Hatzair of Switzerland, began to receive disturbing news about the Jews of Eastern Europe. The Hashomer Hatzair in Switzerland, the only country in unoccupied Europe with a Hashomer Hatzair presence, was relatively well informed about events in the East. It stayed in contact with the various histadruyoth and arranged for the escape of Jewish children from Yugoslavia ${ }^{71}$.

In the course of 1942, the Hashomer Hatzair in Antwerp became interested in joining the Belgian Resistance. The leadership of the movement contacted the communists, but was informed that, though everyone from Hashomer Hatzair was welcome to join the Resistance individually, the movement's joining as a group was not permissible. The Hashomer Hatzair declined these terms and instead began organising on its own ${ }^{72}$. Since the communists refused to supply weapons to the Hashomer Hatzair, they were acquired through a Catholic intermediary. The Hashomer Hatzair organised groups of bogrim who were instructed in the use of arms by a member (krator) who had lived in Palestine in kibbutz Dan and who had likely gained some experience, from the Haganah or the Palmakh, in the use of weapons ${ }^{73}$. However, it seems unlikely that any of these weapons were ever fired, as at this point the Resistance in Antwerp was weak and unorganised. Later, with the departure of most of the bogrim, these weapons were transferred to the communists.

The Hashomer Hatzair also engaged in sabotage and anti-nazi propaganda. Members of the movement wrote and circulated political pamphlets intended to disrupt the German war effort. Young members secretly distributed these pamphlets in the textile workshops, so as to urge the textile workers to stop producing vests and uniforms for German soldiers on the Eastern Front. They also translated newspapers

\footnotetext{
${ }^{71}$ Moreshet, D.1462, letter Yeshayahu Ostri Dan, p. 8 ; Hebrew University Oral History Department. File nr. (27)6, interview with Moshe Nadel.

${ }^{72}$ Cegesoma, interview with Donner David, 00073-00074.

73 Donner, Bericht über die Belgische Tnuah;Cegesoma, interview with Donner David, 0007300074 .
} 
and leaflets about what was happening in the Free World and forged documents, including identity cards ${ }^{74}$.

Even as Hashomer Hatzair became active in the Resistance - thus reversing their principle of not engaging in any work in the galuth the hope of making aliyah nonetheless remained at the forefront of the leadership's thinking. In early 1942, in response to rumours that young Jews were being used for force labour in the construction of the Atlantic Wall (on 11th May 1942 a decree was published that Jews could be called up for forced labour), the leadership decided to pull all bogrim from educational work which was in the hands of the tsofim bogrim. Major debates arose over what should be done. Some in Hashomer Hatzair argued that the older members should head for Switzerland and from there try to reach Erets Israel. Others argued that the older members should stay with the youngsters and if necessary be deported with them, so that they could keep the youth together in the camps. In the end, it was decided that the older members would try to escape to Switzerland. Major reasons for opting in this direction were that younger members were, legally speaking, still under parental guardianship and thus outside any official control of the movement ; moreover, younger members were not considered to be in immediate danger, as only Jews over eighteenwere expected to report for forced labour ${ }^{75}$.

Preparations were now made for the organised escape to Switzerland. Documents were forged and money was collected to bribe officials. Scouts were sent ahead to look for possible routes into Switzerland. When they returned, the bogrim and later some tsofim bogrim were given false documents, instructions and information about meeting points; from June 1942 until August, small groups began their escapes from Belgium and headed for Switzerland ${ }^{76}$. The trip to Switzerland was especially dangerous, not least as all trains and stations were controlled by the Germans. Members had to endure hunger and other hardships as they were smuggled across the mountains to safety.

\footnotetext{
${ }^{74}$ Cegesoma, interview with Donner David, 00073-00074; Hebrew University Oral History Department. File nr. (27)6, interview with Moshe Nadel; personal interview with Rachel Beckmann (maiden name : Lederman) 12.01.2014.

${ }^{75}$ Donner, Bericht über die Belgische Tnuah.

${ }^{76}$ Ibid.;Archives Ein Hakhoresh Etzlenu, p.11, testimony Willy Mohar.
} 
Many of the groups arrived safely in Switzerland; others, however, were caught and transferred to concentration camps. When the members arrived in Switzerland, they sent messages on postcards to assure their comrades in Antwerp of their safe arrival. When no such letters reached Antwerp, the members there knew that the attempt had failed and that the group had been apprehended ${ }^{77}$.

Some members of the hanhagah stayed behind in Antwerp to continue the movement's activities, but the remaining leadership made their way to Switzerland. After raids to round up the Jews in Antwerp began, in the late summer of 1942, those who could flee the city did so. From this point until the end of the occupation, Hashomer Hatzair as an organisation ceased to exist in Belgium. Some members spent the war in hiding and others joined the resistance movement ; many, however, were deported to the East, few of whom returned.

By the end of 1942, some forty members of Hashomer Hatzair Belgium (Antwerp and Brussels), almost exclusively from the older groups, had managed to cross into Switzerland. There they were interned in various detention camps throughout the country. The conditions in these camps were often difficult but the members survived the war and were spared the horrors of the concentration camps. The members received aid and support from the Swiss Hashomer Hatzair, some members with Belgian nationality received aid from the Belgian embassy ${ }^{78}$.

In the summer of 1944, immediately after the opening of the Second Front, two members of Hashomer Hatzair Antwerp prepared to return to Belgium to re-establish the movement. In Switzerland they had received information from Nathan Schwalb, one of the representatives of the World Hekhalutz Office in Geneva ; according to this information, after the war fifty shlikhim would arrive in Europe from Palestine to re-establish the Hashomer Hatzair organisations ${ }^{79}$. The two Hashomer Hatzair members hoped to arrive back in Antwerp before then, so that they could re-establish the movement before arri-

\footnotetext{
${ }^{77}$ Hebrew University Oral History Department. File nr. (27)6, interview with Moshe Nadel. ${ }^{78}$ Donner, Bericht über die Belgische Tnuah;Archives Ein Hakhoresh Etzlenu, p.11.

${ }^{79}$ Cegesoma, interview with Donner David, 00073-00074; for the history of Nathan Schwalb and his relations with the Belgium Zionist movements, see : H. Wagman Eshkoli, op. cit., in D. Michman (ed.), op. cit., pp. 397-417.
} 
val of the shlikhim. The two members crossed the border of Switzerland into France illegally and, together with a female member of the Hashomer Hatzair of France, took the first train they could to Paris, arriving there at the end of August 1944, just after the liberation of the city. After their arrival in Paris they began re-establishing the local ken. In September, after the liberation of Antwerp, they travelled to Belgium and started to reorganise the zionist youth. Initially, because of the small number of zionist youth who remained in Belgium, all the zionist youth movements were organised under one organisation, which called itself HeKhalutz. It was decided that the youngsters would choose later which movement they would like to belong to ${ }^{80}$. This split occurred sometime in 1945, and the Hashomer Hatzair once again became a separate organisation.

In Belgium, the movement was re-established in Antwerp and Brussels, and it maintained good contacts with other zionist youth movements. After the war, the movement helped to absorb refugees who returned to Belgium. A few members who had also survived the camps returned to Belgium and related their awful stories. With the help of the Jewish Brigade, the movement organised a first summer camp (makhaneh) in $1945^{81}$.

Immediately after the war, in the summer of 1945, a large group of members fulfilled their aspirations and set sail for Palestine. Thirtyfive members from the ken of Brussels and Antwerp (possibly also from Liège) departed for Palestine aboard the Mataroa. They arrived at Haifa on 9 September $1945^{82}$.

By 1946, each of the kinim in the main cities of Belgium had renewed its activities, though the dynamics between the different kinim and Jewish life in the cities had been transformed. Antwerp, which the nazis had (with help from the municipality and the active support of Flemish collaborators) rendered Judenfrei more thoroughly than they

\footnotetext{
${ }^{80}$ Cegesoma, interview with Donner David, 00073-00074.

${ }^{81}$ The Jewish Brigade was a combat force in the British army recruited from Jewish volunteers from Mandate Palestine; it fought in the Italian campaign and was later deployed in Belgium and Holland were it was of enormous help to the devastated Jewish community. For more information on the Jewish Brigades activities in Belgium, see: Y. Gelber, « The Jewish Brigade in Belgium », in D. Michman (ed.), op. cit., pp. 477-483.

${ }^{82} \mathrm{CZA}$ (Central Zionist Archives), Organe mensuel édité par le bureau de liaison de Hachomer Hatsair pour les pays de langue française.
} 
had Brussels, now accommodated far fewer Jews. It was easier to reestablish a ken in Brussels, where the Jewish population had fared better. The nucleus of the movement shifted towards Brussels, where a very strong and healthy ken still exists.

Even after the re-establishment of a strong Jewish presence in Antwerp, the ken was unable to regain its former position, primarily due to changes in the social and religious structure of the local Jewish community, which was quickly becoming religiously orientated. The Antwerp ken continued to operate until the 1980's, after which it ceased to exist.

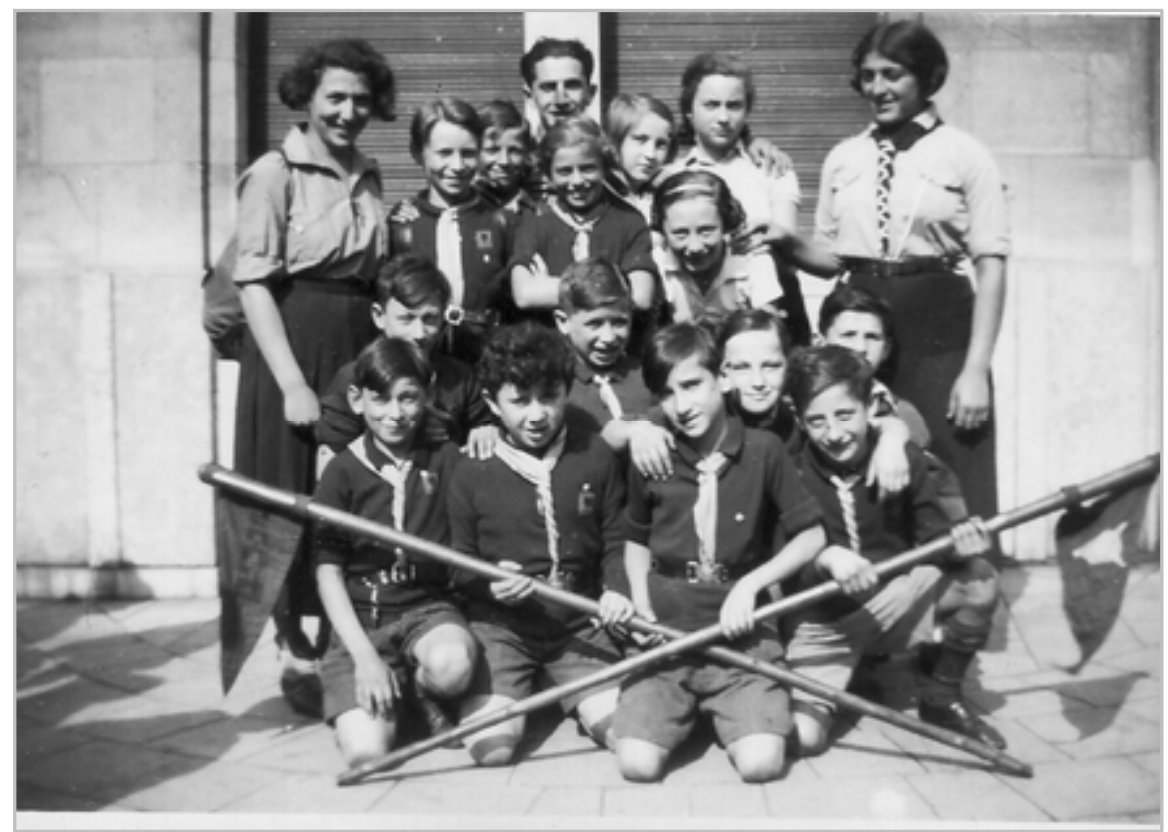

A kvutsa of Hashomer Hatzair Antwerp, 1934.CYad Yaari 


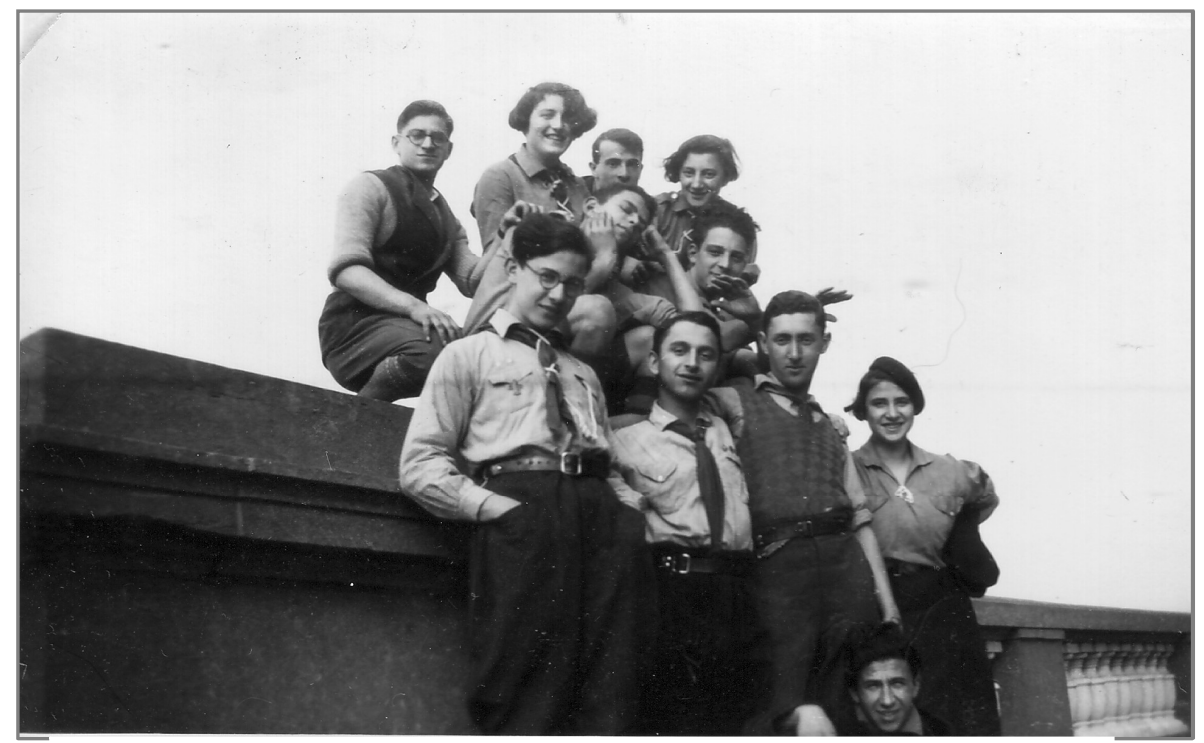

Makhaneh (summercamp) Hashomer Hatzair Antwerp, 1934. CYad Yaari

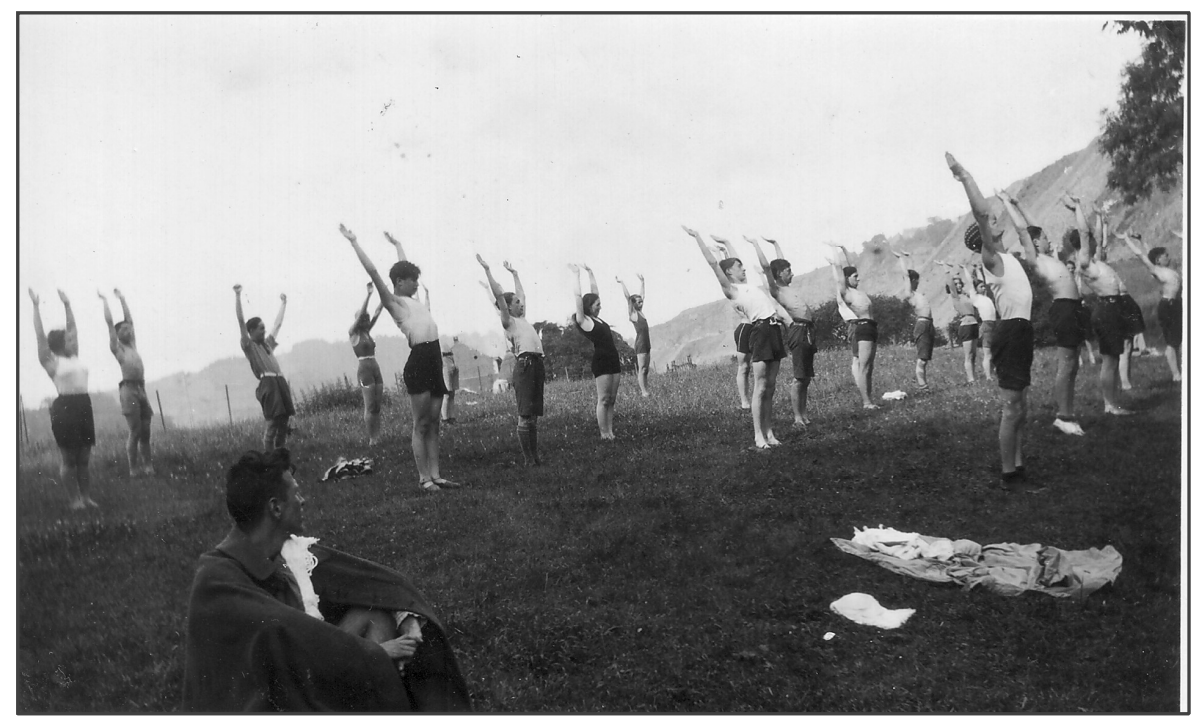




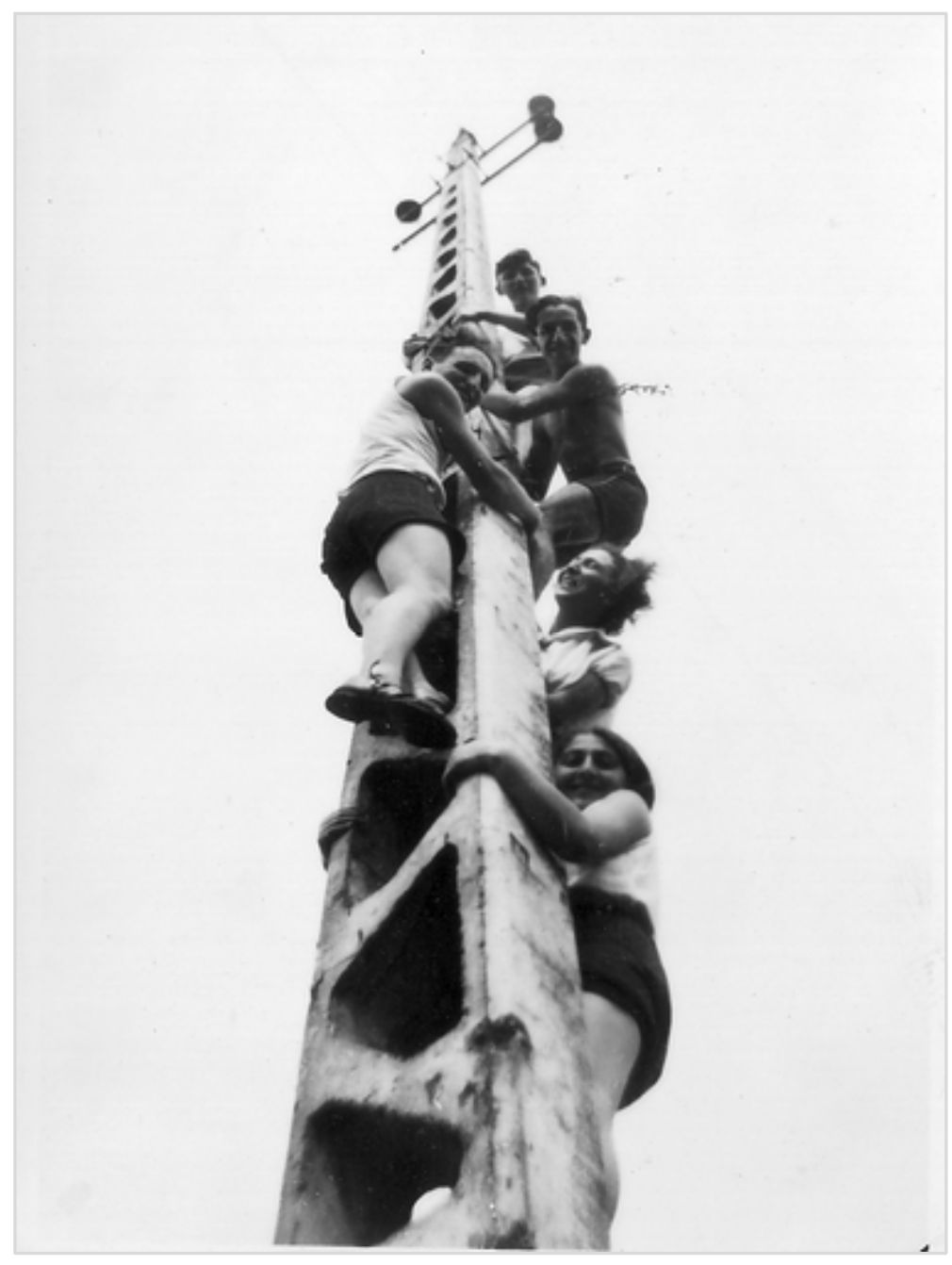

Makhaneh (summercamp) Hashomer Hatzair Antwerp, 1934. CYad Yaari 


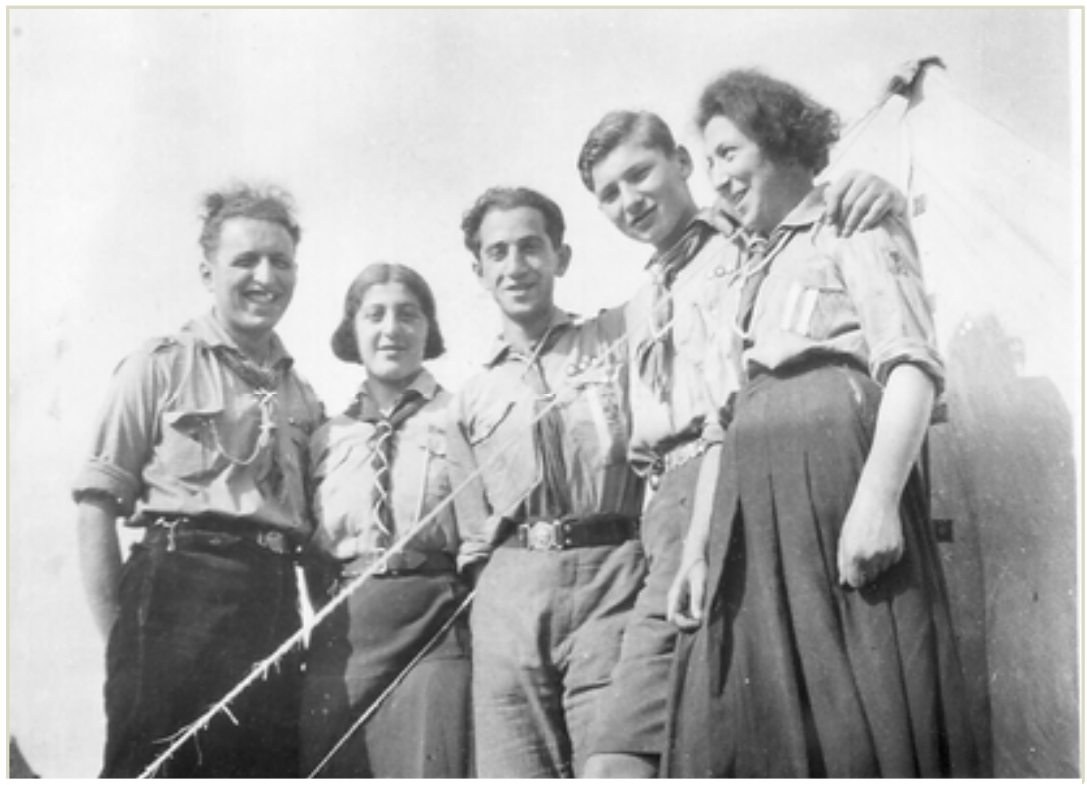

Makhaneh (summercamp) Hashomer Hatzair Antwerp, 1934. CYad Yaari

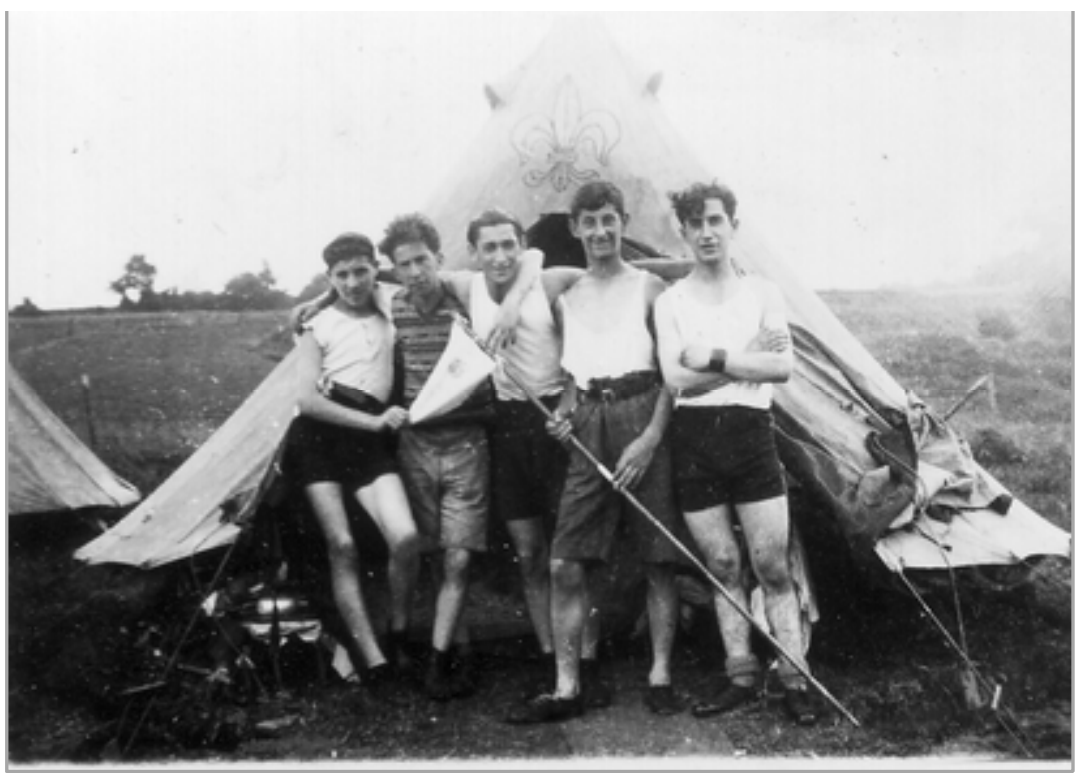




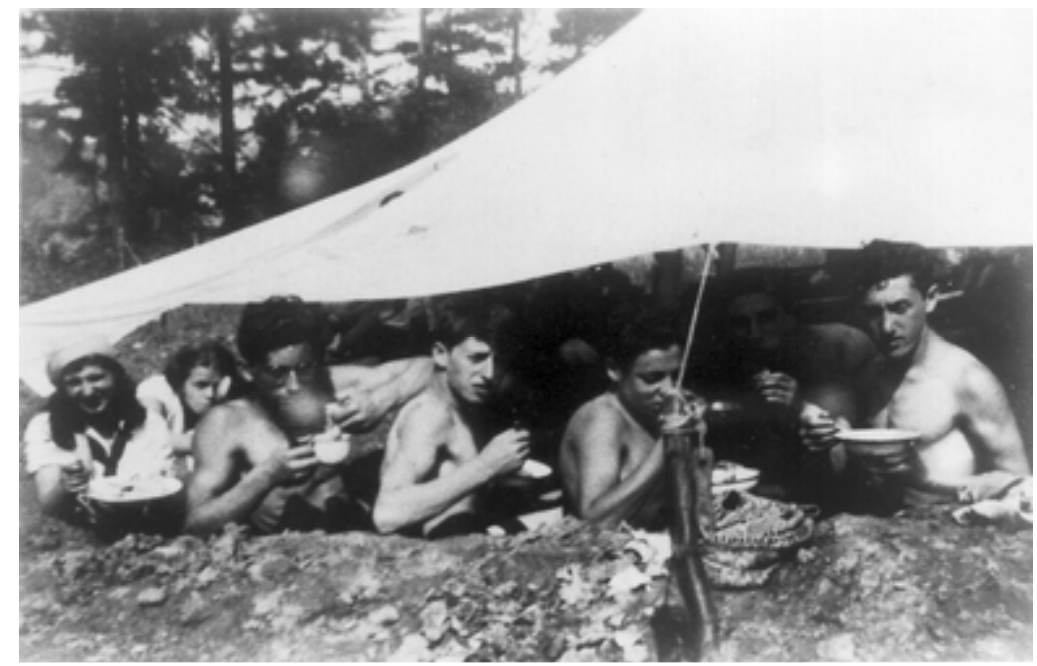

Makhaneh (summercamp) Hashomer Hatzair Antwerp, 1934. CYad Yaari

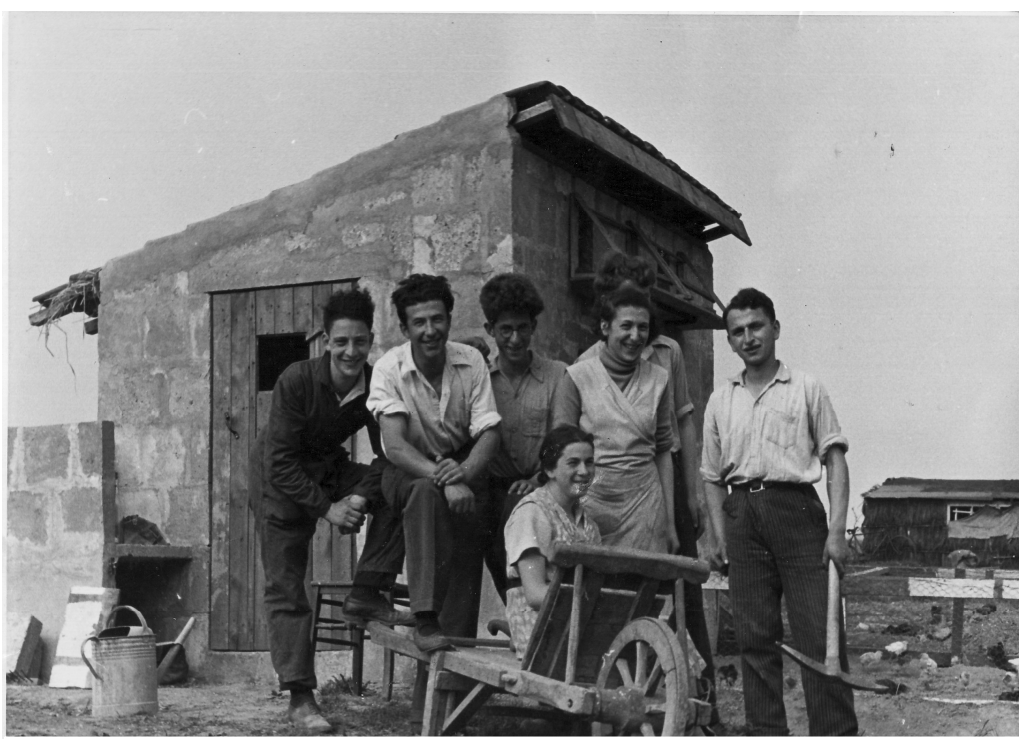

Hakhsharah of Villers-la-Ville (Brabant), 1936.CYad Yaari 